Polonistyka. Innowacje

Numer 1, 2015

DOI: $10.14746 /$ pi.2015.1.1.7

\title{
Wiesława Wantuch
}

Uniwersytet im. Adama Mickiewicza, Poznań

\section{Wojenna rozsypanka}

\section{War puzzle}

\begin{abstract}
The article shows an example of classroom work in junior high school with Milosz's and Szymborska's poems about war. The comparative analysis and different interpretations of its extensions in the work with poetic texts is dealt here in the presence of military themes in popular culture. "Reading through a magnifying glass" can induce a young receiver to a more vigilant behavior in relation to the images of war offered also by Polish cinema.
\end{abstract}

Keywords: school and pop culture vision of war, comparative analysis, collage of fragments.

Co i jak młodzi Polacy myślą o wojnie? Jak bardzo jest to istotny problem w obecnej sytuacji geopolitycznej, w siedemdziesiąt lat po wojnie, w warunkach stabilnego, jak się wydaje, pokoju? Jak młodzież szkolna godzi tę sytuację z ciągłą obecnością wojen, konfliktów, walk w środkach masowego przekazu? Jak obrazy wojen w kulturze popularnej, w grach komputerowych, w filmach dokumentalnych lub uczestnictwo np. w rekonstrukcjach historycznych bitew wpływają na stosunek do wojny? Jak wobec tych różnorodnych ujęć sytuują się poznawane w szkole obrazy wojny? Czy lektur o tematyce wojennej jest na lekcjach polskiego za mało, czy za dużo? Czy i jak kształtują one dojrzewanie młodych ludzi do tej problematyki i ich świadomość historyczną? Wobec takich pytań staje polonista pragnący skłonić młodzież do refleksji nad wojną jako doświadczeniem egzystencjalnym, o którym, niestety, nie tylko Albert Einstein myślał: „Dopóki na świecie będzie istniał człowiek, będą też wojny".

Jeszcze inaczej tę sprawę widzi Przemysław Czapliński, pisząc: „II wojna światowa trwa nadal. My ją toczymy, a ona toczy nas. (...) Obszarem, na którym prowadzone 
są działania wojenne, jest front symboliczny” (Czapliński 2006, 417). Obecnie przewagę mają na nim nieliterackie obrazy wojny i dlatego to one stanowią naturalny punkt odniesienia dla lektur proponowanych w szkole. Świadoma tego sięgam po polskie filmy lat ostatnich, aby wzbogacić i uzasadnić czytanie „przez lupę” poetyckich świadectw myślenia o wojnie.

\section{Wojna zaczyna się w głowach!}

We wrześniu 2014 r. na pytanie Czy wojna jest skutecznym sposobem rozwiąywania konfliktów między państwami? ponad 88\% Polaków odpowiedziało Zdecydowanie nie lub Raczej nie. Wśród tych, którzy opowiedzieli się za wojną (3\%), najsilniejsze korelacje widać było między ich poglądami na tę sprawę a gotowością do agresji interpersonalnej. Osoby te akceptowały przemoc słowną i fizyczną w polityce oraz postrzegały relacje społeczne jako antagonistyczne. Z kolei Krystyna Skarżyńska w prowadzonych przez siebie badaniach znalazła potwierdzenie ustaleń psychologa Thomasa Gilovicha (z lat 80. XX w.), że ,analogie historyczne, nawet gdy są oparte na mglistych podobieństwach, znacząco wpływają na opinie o aktualnym konflikcie oraz na preferowane sposoby jego rozwiązania" (Skarżyńska 2015). Nie bez znaczenia jest fakt, że CBOS sondaż przeprowadzało w cieniu wojny na Ukrainie, gdy często przywoływano w środkach masowego przekazu analogię między aneksją Krymu przez Rosję a przyłączeniem Austrii do Niemiec przez Hitlera w 1938 roku. Z takim porównaniem zgodziło się aż 53,3\% Polaków.

Ktoś, kto zajmuje się wychowywaniem młodzieży, powinien zmierzyć się z problematyką wojenną bez względu na to, że żyje w czasach pokoju, ale również pokazywać młodzieży subtelne znaki tęsknoty za radykalnym rozwiązywaniem konfliktów, przejawiające się w estetyzacji wojny, w postępującym znieczuleniu na jej obrazy. Ponieważ wojna najpierw podbija umysły, warto zaszczepić w młodych ludziach wrażliwość pozwalającą we współczesnej rzeczywistości wcześnie wykrywać, jeszcze rozproszone, ale już niebezpieczne sygnały nadciągającej wojny. Tą swoistą szczepionką intelektualną mogą być teksty antywojenne, nieszukające odpowiedzi na to po czyjej stronie jest racja ani nieodwołujące się do konkretnych konfliktów, często jednak nimi inspirowane. Wiersze Czesława Miłosza i Wisławy Szymborskiej są dlatego tak trudne w odbiorze szkolnym, bo nie oskarżają zbrodniarzy, ale pokazują, jak wojna przenika w tkankę świata, znajduje dostęp do serc i umysłów, jaka jest podstępna, nawet gdy już wygaśnie. 


\title{
Wiersze zmiksowane
}

Lekcje $^{1}$, które opisuję, zaczęłam się od rozdania tekstu - kolażu fragmentów dwóch wierszy: Piosenki o porcelanie Czesława Miłosza i Końca i początku Wisławy Szymborskiej² (patrz: załącznik). Uczniom zlecono „śledztwo” w tej sprawie. Poprzez zadawanie pytań mieli ustalić genezę tekstu. Wiedzieli jedynie, że jest to tekst spreparowany na potrzeby zajęć. Na wstępie ustalili, że mają przed sobą opis jakiejś katastrofy, zniszczenia, ale i starań zmierzających do ratowania domu, przywrócenia ładu. Zwrócili także uwagę na refren, który „brzmi jakoś inaczej niż strofy”, a i te różnią się między sobą liczbą wersów. Najistotniejsze pytania, które zaproponowali gimnazjaliści, dowodziły, że wahają się między poszukiwaniem spójności i różnic wewnątrz tekstu:

\author{
Kto do kogo mówi? \\ Czy ta sama osoba mówiąca zabiera głos we wszystkich strofach i w refrenie? \\ Czy „ktoś” jest tym, do kogo w refrenie mówi się „proszę pana”, a w drugiej strofie \\ „spojrzysz”; czy tym, kto to mówi?
}

Wątpliwości było więcej: w strofach pierwszej i trzeciej dominuje skupienie na detalu, a w drugiej pojawia się szersza perspektywa opisu, ale w poezji taka zmiana punktu widzenia nie jest niczym niezwykłym. Tutaj przypomniałam, że wiersz z reguły czytamy nielinearnie, inaczej niż prozę. Wracamy do niektórych miejsc, często przyglądamy się jego organizacji pionowej. Nadanie spójności tekstowi poetyckiemu w większym stopniu niż w prozie leży po stronie czytelnika. Poza tym spójność jest także kwestią konwencji. Kultura współczesna dopuszcza w tym względzie większą swobodę, dlatego też pozwoliłam sobie „zmiksować” dwa teksty na podobny temat, co wcale niełatwo wykryć osobom nieznającym oryginałów.

Następnie wysłuchaliśmy Piosenkę o porcelanie w wykonaniu Jacka Telusa ${ }^{3}$. Uczniom sprawiło satysfakcję to, że już wcześniej sami zwrócili uwagę na rytmiczność i bliskie rymy refrenu, co jest charakterystyczną cechą piosenki. Potwierdziła się także ich hipoteza, że tematem zasadniczym jest kataklizm. Dopiero gdy otworzyli podręczniki, zdziwili się, iż autorem słów wysłuchanego utworu jest Czesław Miłosz. Wyjaśniliśmy sobie,

\footnotetext{
${ }^{1}$ Lekcje (2 x 45 min.) stanowiące inspirację do tego artykułu zostały przeprowadzone 09.05.2014 w kl. III b Gimnazjum Dwujęzycznego im. Karola Marcinkowskiego w Poznaniu.

${ }^{2}$ Klasa, w której prowadziłam lekcje, korzystała z podręczników To lubię, tu: Podręcznik do języka polskiego. Teksty $i$ zadania. Klasa 3 gimnazjum, Kraków 2001, gdzie omawiane wiersze Szymborskiej i Miłosza zamieszczono odpowiednio na s. 229 i 224 w dziale Uwikłani w historię, podrozdział Tam, kędy przeszly tanki. Zapoznałam się także z kierunkiem interpretacji proponowanym w Książce nauczyciela.

${ }^{3}$ Muzyka: Jacek Telus; z płyty: tegoż: Miłosz w muzyce, muzyka w Miłoszu, Agencja Muzyczna Polskiego Radia, 2010.
} 
że to przykład poezji śpiewanej, ale skoro w tytule wiersza, pierwotnie nie do śpiewania, pojawia się słowo piosenka, to wiersz powinien wpadać w ucho. Sugestia, że piosenka zapowiada treści mniej poważne niż pieśń, nie trafiała uczniom do przekonania. Rozróżnienie pieśni i piosenki okazało się zbyt arbitralne. Gimnazjaliści zwrócili natomiast uwagę przede wszystkim na oprawę muzyczną i sposób wykonania wysłuchanego utworu. Zauważyli na przykład, że choć głos wykonawcy „rwie się”, to dźwięk instrumentu, który przypomina cymbałki, tworzy tło muzyczne „lekkie” i „taneczne”.

Uczniowie początkowo uznali tekst za monolog kogoś, kto ogląda ogrom zniszczeń, ale potem dostrzegli milczącego towarzysza (co może wskazywać na pozorowany dialog), wobec którego osoba mówiąca wyraża żal z powodu strat. Udało się uściślić przyczynę tych strat - wojnę (tam kędy przeszły tanki). Klasa spontanicznie podzieliła się na dwie grupy. Jedni uważali, że żal po stracie porcelany jest małostkowym przejawem braku wrażliwości wobec dramatu, który dokonał się niedawno. Irytowały ich zdrobnienia dotyczące nie tylko zastawy (spodeczki, skorupki), ale i pejzażu (rzeczka, wietrzyk). Drudzy uznawali, że zniszczenie porcelany symbolizuje wszystko, co kruche i wobec czołgów nie ma szans, a więc na przykład wszelkie dzieła sztuki (sny majstrów drogocenne), ale także subtelne uczucia, wrażliwą psychikę, które wojna „zawsze miażdży”.

Wróciliśmy do opisowych ujęć. Zgodzono się, że w wierszu Miłosza jest to szerokie ujęcie pejzażowe, żeby nie powiedzieć „landszaftowe” - nie tylko rzeczka, ale i jutrzenka, równina do brzegu słońca przywołują takie skojarzenia. Egzaltację w ujęciu krajobrazu sugerowały uczniom przede wszystkim zdrobnienia, konstrukcje składniowe (uznane przez młodych czytelników za zawiłe) oraz retoryczne zwroty kierowane do przedmiotów martwych (apostrofy), a zwłaszcza słowa odczuwane przez młodzież jako archaiczne, np. ruczaje, kurhany. Uświadomiłam sobie wtedy, że określenia pejzaż polski lub kresowy są zakodowane w mojej świadomości, ale uczniom należy je przywołać obrazami np. Józefa Chełmońskiego czy Stanisława Masłowskiego, a jeszcze lepiej amatorskimi ujęciami tego tematu, powielanymi także na współczesnych zdjęciach, które łatwo odnaleźć w Internecie.

Przyroda u Miłosza pozostaje prawie nienaruszona. Jedynie złamanej cień jabłoni każe w tym pejzażu dostrzec odbicie raju. Natomiast owe puchy z pierzyny, bryzgi kruchej piany, trzaski i zgrzyty spodeczków o niezwykłej urodzie to odpryski ludzkiego, już nieistniejącego świata, które skupiają uwagę zadumanego świadka. Uczniowie niechętni jego czułości do filiżanek uparcie nazywali go spacerowiczem. W grupie oponentów pojawiło się przypuszczenie, że być może zwrot proszę pana jest zwrotem do Boga. W ten sposób poszu- 
kiwano godniejszego uzasadnienia piosenki-skargi, której można by przypisać rangę modlitwy. Sprowokowały do tego i dywagacje na temat raju, i obecność kurhanu w opisie krajobrazu.

Bardziej nośny niż ta ścieżka interpretacyjna okazał się namysł nad tym, jak znaczenie słowa zmieniają epitety: brzydka zakrzepła (farba), świeże (kurhany). Zakrzepła to najczęściej określenie krwi - zauważyła jedna z uczennic i uznała to za próbę niemówienia wprost, eufemizm, co potwierdzałoby uznanie osoby mówiącej w wierszu za kogoś, kto woli nie widzieć większych nieszczęść niż utrata serwisu. Drugie z kolei słowo odczuwane jako archaiczne przywołuje przeszłość po to, aby zilustrować powtarzalność wojennych kataklizmów. Nawroty „epizodów” wojennych w historii wpisują się w następstwo rajskich pejzaży i „krajobrazów po bitwie” w sztuce. Piosenke o porcelanie można zatem odczytać jako gorzką konstatację, że wojny od zawsze niszczą prywatne arkadie i w pył obracają to, co najbardziej kruche i wartościowe lub jako małostkowy lament kogoś, kto dba tylko o swoje bibeloty i chroni się w stylizowanym na raj pejzażu, nie bacząc na losy prawdziwych ofiar i pomijając przyczyny wyniszczającego konfliktu. Niezależnie od tego jest to tekst, który konstruuje jakąś indywidualną osobową wizję zniszczeń wojennych uzyskaną poprzez subtelną kreację językową. Jako wątek uboczny tych rozważań pojawiło się pytanie, czy jest tu jakaś perspektywa nadziei? Gimnazjaliści nie dostrzegli takiej szansy, na taki trop nie naprowadza także osoba mówiąca w wierszu, skłonna jedynie do obrony swojego stanu posiadania, a prawdziwe straty maskująca eufemizmami.

\section{Piosenka o końcu i początku}

W drugiej części zajęć kategorie, które interesowały nas wcześniej, spróbowaliśmy przyłożyć do wiersza Szymborskiej i znowu odpowiedzieć sobie: Kto do kogo mówi? Jaki pejzaż jest opisany i z jakiej lub czyjej perspektywy? Jakie przesłanie dotyczące wojny jest ukryte w tym ,pejzażu”?

Głos z Końca i początku uznano za bardziej bezosobowy niż u Miłosza. Być może to korespondent wojenny, który właśnie wybiera się na następną wojnę, albo ktoś świadom praw historii z cynicznym dystansem opisuje żmudną krzątaninę ocalałych przy przywracaniu porządku. Ogrom zniszczeń poznajemy pośrednio; zamiast krajobrazu po bitwie czytelnik zostaje zapoznany z wykazem czynności, które ktoś musi wykonać oraz zmian, którym świadomość zbiorowa podlega najpierw tuż po wojnie, a potem w coraz większym od niej oddaleniu. 
Gimnazjaliści uznali, że bohaterem tego ,poetyckiego reportażu” jest ktoś, czyli anonimowa zbiorowość. Ktoś jest zaimkiem w liczbie pojedynczej, ale Szymborska używa go po to, aby stworzyć iluzję, choć anonimowego, to jednak pojedynczego udziału w dziejach kogoś, czyje działania wchodzą w skład czynu zbiorowego, a czasem stanowią o kierunku przemian zbiorowości lub są ich wyrazem. Uczniowie zauważyli, że ktoś oznacza jednostkę konstruktywnie współdziałającą ze wszystkimi w powojennej odbudowie, by w części drugiej (od słów Ktoś z miotła w rękach) przynależeć do mniejszej już grupy tych, co opowiadają lub słuchają opowieści o tym, jak było. Pojawiają się bowiem już inni, których to nudzi. Z czasem to oni zastępują świadków i budowniczych. Ostatnia strofa wywołała spór, do której z tych grup przynależy ktoś w niej opisany:

\footnotetext{
W trawie, która porosła

przyczyny i skutki,

musi ktoś sobie leżeć

z kłosem w zębach

i gapić się w chmury.
}

Jedni twierdzili, że to ów ktoś z pierwszej części, kto wreszcie jest sam, uwolniony od bagażu traumatycznych przeżyć zbiorowych. Drudzy pragnęli, by reprezentował beztroskę nowego pokolenia, które buja w obłokach, bo miniona historia (i wojny, i czasu odbudowy) zupełnie go nie dotyczy. Marzy o innym porządku dziejów. Tę interpretację zaburzyło pytanie: W jakiej trawie leży ten „marzyciel” i co to może znaczyć? Pomogło nawiązanie do tytułu - naturalne zazwyczaj następstwo etapów każdego procesu to właśnie początek i koniec. Koniec wojny dla mediów oznacza, niestety, konieczność szukania następnej. Dla uczestników właśnie zakończonego konfliktu oznacza z kolei początek odbudowy; ale najbardziej gorzkie jest to, że dla przyszłych pokoleń to wszystko będzie miało coraz mniejsze znaczenie. I być może ów „marzyciel” niepomny przyczyn i skutków „wymarzy” sobie następną wojnę... W tej perspektywie koniec wojny jest początkiem nie tylko lepszej przyszłości. Obok zaimka ktoś, powtórzonego w tekście dziewięć razy, czasownik musi występuje równie często, zwłaszcza jeśli uwzględni się elipsę w czwartej zwrotce i synonimy o równie kategorycznym wydźwięku jak np. wymaga, trzeba. W ten sposób wyrażono przekonanie podmiotu mówiącego o nienaruszalności praw historii, napędzanych rytmem pamięci i zapominania. 


\section{Po co mi to?}

Odniosłam wrażenie, że podczas tych lekcji młodzież została postawiona przed zbyt trudnymi zadaniami, których wykonanie nie miało dla nich osobistego, egzystencjalnego przełożenia. Nie zdążyłam dowiedzieć się, co gimnazjaliści myślą o wojnie. Po lekcji polonistka na co dzień pracująca w tej klasie zapytała, po co posłużyłam się kolażem na początku, skoro kategorie podmiotu mówiącego, pejzażu lirycznego można było wprowadzić od razu i zyskać przy tym na czasie. Dla mnie jednak ważne było to, że uczniowie sami zechcieli posłużyć się nimi przy rozwiązywaniu początkowej „zagadki”. To zadanie (trudne, ale bardziej istotny był tu proces niż wynik) miało bowiem w założeniu pokazać, czy uczniowie potrafią posługiwać pojęciami literaturoznawczymi, a poza tym stanowiło atrakcyjne (w moim mniemaniu) wprowadzenie do analizy porównawczej. Nie w pełni to potem wyzyskałam. Sądzę, że większą samodzielność uczniów można sprowokować, stawiając na kontrast, co wymusza zapis linearny wybranych zwrotek i refrenu. Proza wyraziściej ujawnia niespójności tekstu:

\footnotetext{
Część 1 tekstu:

Różowe (...) spodeczki, kwieciste filiżanki leżą (...) na brzegu rzeczki, tam kędy przeszły tanki. Wietrzyk nad [nimi] polata, puchy z pierzyny roni. Na czarny ślad opada złamanej cień jabłoni. Ziemia, (...) zasłana bryzgami kruchej piany.

Część 2 tekstu:

Ktoś musi zepchnąć gruzy na pobocza dróg, żeby mogły przejechać wozy pełne trupów. Ktoś musi grzęznąć w szlamie i popiele, sprężynach kanap, drzazgach szkła i krwawych szmatach. Ktoś musi przywlec belkę do podparcia ściany, ktoś [musi] oszklić okno i osadzić drzwi na zawiasach.
}

Potem, gdy już ujawni się oba oryginały, wystarczy podejrzenia ugruntować, odpowiadając powtórnie na pytania:

Które z tych wydarzeń odbyło się wcześniej, które później? Wnioski wyprowadź z analizy języków obu części tekstu i wierszy.

Czym opis pierwszej części różni się od drugiej? Jakie „plany filmowe” zastosowano?

Co, Twoim zdaniem, zdarzyło się w opisanym świecie? 
Przypuszczam, że praca nad prozą lepiej przygotowuje do analizy tekstów w całości niż ,zmiksowany” wiersz, zwłaszcza gdy uczniowie pracują w grupach. Ich spostrzeżenia łatwo zestawić w tabeli.

\begin{tabular}{|c|c|c|}
\hline Kryterium & Pierwsza część tekstu & Druga część tekstu \\
\hline Co się zdarzyło? & kataklizm, wojna (tanki) & kataklizm \\
\hline Wskaźniki czasu & $\begin{array}{l}\text { słownictwo z innego rejestru: } \\
\text { „dawniejsze”, bardziej } \\
\text { wyszukane: kędy, tanki, roni; } \\
\text { rymy: filiżanki/tanki, } \\
\text { roni/jabłoni } \\
\text { Hipoteza: tekst } 1 . \text { powstał } \\
\text { wcześniej niż tekst } 2 .\end{array}$ & $\begin{array}{l}\text { język potoczny, rzeczowy, } \\
\text { nawet nakazowy }\end{array}$ \\
\hline Rodzaj/techniki opisowości & $\begin{array}{l}\text { Pejzaż, w którym obecne są } \\
\text { niepokojące detale. Plany } \\
\text { filmowe: plan ogólny + } \\
\text { detale. Opis bezpośredni, } \\
\text { bardziej statyczny niż w } \\
\text { tekście } 2 \text {. }\end{array}$ & $\begin{array}{l}\text { Opis pośredni, w ruchu. } \\
\text { Poprzez zakres czynności } \\
\text { „do wykonania” opisano } \\
\text { ogrom zniszczeń. Plany } \\
\text { filmowe: krótko plan ogólny } \\
\text { + plany pełne. }\end{array}$ \\
\hline
\end{tabular}

Takie wprowadzenie pozwala zwrócić uwagę na różnorodne techniki i funkcje opisu. Kiedy zaś uczniowie zapoznają się z całym utworem Miłosza i porównają go z urywkiem „przełożonym” na prozę, dostrzegą, że pozorny „obiektywizm” opisu zostaje w oryginale zaburzony apostrofą i zaimkiem moje. Uczulimy ich wówczas na podobne sygnały w pozostałych częściach wiersza. Zaś refren wyraźnie wydobędzie potencjalną interakcyjność tego monologu, a nawet możliwość przypisania go „drugiej” osobie dialogu. Te działania skłaniają do skupienia niezbędnego przy czytaniu ,przez lupę”, do czego gimnazjaliści nie są zbyt skłonni. Z kolei informacje bibliograficzne wskazujące, z jakich tomów pochodzą utwory i kiedy powstały, mogą potwierdzić lub podważyć uczniowskie wnioski wynikające z analizy słownictwa, a przy okazji będą sprawdzianem ich wiedzy historycznej. Wiersz Miłosza powstał przecież krótko po II wojnie światowej, a Szymborska pisała Koniec i początek w obliczu narastającego konfliktu w byłej Jugosławii. Znajomość lub nieznajomość tych faktów pozwoli zaś młodym ludziom na samych sobie zweryfikować przekonanie poetki o potencjalnym związku zapominania ze zmianą postawy wobec wojny. 


\section{Wojna i „fajność”}

Zwykle jednak dopiero zderzenie poetyckiego języka ze współczesnymi obrazami filmowymi podgrzewa temperaturę i refleksji, i dyskusji. A ostatnimi czasy przybyło nam takich filmów, choćby tylko w 2014 roku swoją premierę miały Kamienie na szaniec (reż. Robert Gliński), Powstanie Warszawskie, Miasto 44 (reż. Jan Komasa). Wokół nich rozgorzały spory. Tadeusz Sobolewski pisał na przykład, iż film Komasy, mimo że miał większe ambicje, zderzył się z falą powstańczego, bezrefleksyjnego kiczu: gra na emocjach, przygniata widza efektami w hiperrealistycznych scenach. „Melodramat dwudziestolatków, ich miłosną inicjację zderza z wizją apokalipsy" (Sobolewski 2014), którą dzieli na mistrzowskie kadry. Powoli historia, nawet ta wojenna, „staje się materiałem, z którego dowolnie wycina się własne i społeczne fantazje" (Jarecka 2014). Czy to nie wytwór wyobraźni „marzyciela” z ostatniej strofy Końca i początku? Kolekcja mody Heroes Roberta Kupisza inspirowana Powstaniem Warszawskim, zresztą dobrze przyjęta na rynku, to typowy przykład komercjalizacji hekatomby, który każe sądzić, że niewiele osób potrafi odczytać film Komasy równie przewrotnie jak Agnieszka Graff: „To nie kicz wojenny, tylko 'antywojenny' metakicz, ironiczna kpina $\mathrm{z}$ idealizacji przemocy, cierpienia, śmierci” (Graff 2014). To z tytułu jej felietonu skorzystałam w śródtytule, aby podkreślić możliwe gry z atrakcyjnością tematu wojennego, która może wciągnąć część młodych odbiorców, choć inni mają wobec takiej gry zastrzeżenia. Od znajomej licealistki usłyszałam: „Albo realizm, albo wideoklip! Kiedy oni się całują, a pociski zawracają, zatrzymane siłą ich miłości, to ja się gubię”. Częściej niż do krytycznego zderzenia estetyk i symboliki w przypadku filmów i lektur o wojnie (zwłaszcza o naszej wojnie) polonista decyduje się na porównywanie wartości i stawia pytanie o to, czy współczesna młodzież jest w stanie się tak poświęcić. O ile to pierwsze działanie nauczyciela wydaje się zasadne, bo skłania do namysłu nad sobą, choćby takiego: „My mamy więcej gadżetów i tym się zajmujemy, a oni mogli zajmować się przede wszystkim sobą. I to było piękne". (Michalewicz 2014), o tyle najlepszym komentarzem do drugiego jest stwierdzenie Waldemara Łazugi: „Co innego roztrząsać tragiczne momenty w życiu ludzi i narodów, co innego wychowywać w kulcie ofiary”, (Łazuga 2014).

Uważam, że wiersze takie jak powyżej rozważane, każą spojrzeć młodym czytelnikom na wojnę jako na graniczne wydarzenie w życiu jednostki bardziej nawet niż zbiorowości. Co więcej, stanowią istotne uzupełnienie, a może przeciwwagę dla propozycji popkulturowego (nawet jeśli to jest popkultura wysokiego lotu) podejścia do tematu. Wnikliwa interpretacja z różnych perspektyw uczy dystansu, nie wymuszając konieczności 
opowiedzenia się po którejś stronie, „my” lub „oni”, niezależnie od tego, czy „oni” to wrogowie, czy bohaterowie będący często rówieśnikami młodzieży gimnazjalnej. Analizowane utwory poetyckie mogą prowokować do spojrzenia, jak skonstruowana jest dana poetycka opowieść o wojnie, a także inspirować do swoistej intelektualnej gry, jaką można prowadzić z ich wsparciem w określonym kontekście społeczno-kulturowym. A być może chronią również przed takimi deklaracjami, jak ta wygłoszona po obejrzeniu Miasta 44: „Za tamtą Polskę mogłabym walczyć. Za tę, w której żyję - nie sądzę” (Michalewicz 2014). To przecież gorzkie poświadczenie tezy Czaplińskiego wyprowadzonej z powiedzenia Clausewitza, że wojna jest przedłużeniem normalności rozgrywanej innymi środkami: „Z normalnego życia zwykłych ludzi wyrastają zwyczaje wojowania i niesienia pomocy (...) Heroizm i okrucieństwo czasów wojny i okupacji zawsze wyrastają $z$ gleby zwykłości” (Czapliński 2006, 437). Może wojna i pokój nie są tak przeciwstawne sobie, jak zwykliśmy sądzić?

\section{Załącznik (materiał wykorzystany na lekcji)}

Ktoś musi grzęznąć

w szlamie i popiele,

sprężynach kanap,

drzazgach szkła

i krwawych szmatach.

Niczego mi, proszę pana,

Tak nie żal jak porcelany.

Na czarny ślad opada

Złamanej cień jabłoni.

Ziemia, gdzie spojrzysz, zasłana

Bryzgami kruchej piany.

Niczego mi, proszę pana,

Tak nie żal jak porcelany.

Ktoś musi przywlec belkę

do podparcia ściany, 
ktoś oszklić okno

i osadzić drzwi na zawiasach.

Niczego mi, proszę pana,

Tak nie żal jak porcelany.

\section{Bibliografia:}

Czapliński Przemysław, 2006, Wypowiadanie wojny. Literatura najnowsza wobec okresu 1939-1945, w: Buryła S., Rodak P. (red.), Wojna. Doświadczenie i zapis, nowe źródła, problemy, metody badawcze, Kraków, s. 417-439.

Graff Agnieszka, 2014, Bohaterstwo i fajność, „Wysokie Obcasy” 11 X.

Jarecka Dorota, 2014, Polskie pożegnanie z trauma, „Gazeta Wyborcza” 26-27 VII.

Łazuga Waldemar, 2014, w: Szyłł, Pytam x 3 (cykl), Uczyć dzieci, że należy poświęcać życie za ideę albo ojczyznę? , „Gazeta Wyborcza” - „Duży Format” 7 VIII.

Michalewicz Iza, 2014, Iza Michalewicz oglada z maturzystami „Miasto 44”, „Gazeta Wyborcza” - „Duży Format” 2 X.

Skarżyńska Krystyna, 2015, Wojna zaczyna się w głowach, „Gazeta Wyborcza” 7-8 III.

Sobolewski Tadeusz, 2014, O której skończy się powstanie? „Gazeta Wyborcza” 31 VII.

Wieslawa Wantuch - doktor nauk humanistycznych, nauczycielka akademicka, wcześniej praktykująca w szkole podstawowej, obecnie członek Pracowni Innowacji Dydaktycznych Uniwersytetu im. Adama Mickiewicza w Poznaniu. Autorka Aspektów integracji w nauczaniu języka polskiego (2005), Gier słów i rzeczy (2006) i licznych artykułów w „Polonistyce”. 